\title{
Gambaran Tingkat Kecemasan Ibu Hamil Primigravida Trimester III di Klinik Bersalin Sutra Minahasa Selatan
}

\author{
${ }^{1}$ Frincia P. Maki \\ ${ }^{2}$ Cicilia Pali \\ ${ }^{2}$ Hendri Opod
}

\author{
${ }^{1}$ Program Studi Pendidikan Dokter Fakultas Kedokteran Universitas Sam Ratulangi Manado \\ ${ }^{2}$ Bagian Psikologi Fakultas Kedokteran Universitas Sam Ratulangi Manado \\ Email: putriliamaki19@gmail.com
}

\begin{abstract}
Anxiety during pregnancy is often found among primigravidas, especially in the third trimester. Psychological disorders during pregnancy is associated with the occurrence of uterin artery resistance that might cause stunted fetal growth, premature birth, higher risk of premature baby, and even miscarriage. This study was aimed to obtain the anxiety level of third semester primigravidas at the South Minahasa Sutra Clinic. This was a descriptive study with a cross-sectional design. Hamilton Anxiety Rating Scale was used to obtain the level of anxiety. Respondents were all third semester primigravidas who visited the Sutra Clinic in the period of September to November 2018. The results showed that there were 32 respondents in this study. The anxiety levels of respondents were as follows: moderate anxiety in 14 respondents $(43.8 \%)$, severe anxiety in 10 respondents $(31.3 \%)$, and mild anxiety in 6 respondents $(18.8 \%)$. There were 2 respondents $(6.3 \%)$ who did not have anxiety. Conclusion: In the Sutra Clinic, the most common anxiety among the third semester primigravidas was moderate anxiety, followed by severe anxiety and mild anxiety.

Keywords: third semester primigravidas, anxiety, Hamilton Anxiety Rating Scale
\end{abstract}

\begin{abstract}
Abstrak: Kecemasan selama kehamilan sering ditemukan pada ibu hamil primigravida, terutama pada trimester ketiga. Gangguan psikologis selama kehamilan berhubungan dengan terjadinya resistensi pada arteri uterin yang menyebabkan pertumbuhan janin terhambat, kelahiran sebelum waktunya, risiko melahirkan bayi prematur, bahkan sampai keguguran. Penelitian ini bertujuan untuk mendapatkan gambaran tingkat kecemasan ibu hamil primigravida trimester III di Klinik Sutra Minahasa Selatan. Jenis penelitian ialah deskriptif dengan desain potong lintang. Hamilton Anxiety Rating Scale digunakan untuk mengukur tingkat kecemasan. Responden penelitian ialah seluruh ibu hamil primigravida trimester III yang berkunjung ke Klinik Sutra pada periode September sampai November 2018. Hasil penelitian mendapatkan sebanyak 32 responden. Tingkat kecemasan pada responden ialah kecemasan sedang sebanyak 14 responden $(43,8 \%)$, kecemasan berat 10 responden $(31,3 \%)$, kecemasan ringan 6 responden $(18,8 \%)$, dan tidak memiliki kecemasan 2 responden $(6,3 \%)$. Simpulan: Tingkat kecemasan ibu hamil primigravida trimester III di Klinik Sutra yang terbanyak ialah kecemasan sedang, diikuti kecemasan berat dan kecemasan ringan.

Kata kunci: ibu hamil primigravida trimester III, kecemasan, Hamilton Anxiety Rating Scale
\end{abstract}

Umumnya ibu yang belum pernah melahirkan mengakui bahwa mengalami cemas saat akan melahirkan dikarenakan tidak ada pengalaman menjadi seorang ibu. Semakin tua kehamilan maka kecemasan dan keta- kutan yang dialami ibu hamil akan meningkat menjelang persalinan. ${ }^{1,2}$ Kecemasan pada ibu hamil dapat timbul khususnya pada trimester III. Kecemasan yang dialami antara lain jenis kelamin bayi yang belum 
pasti, normal atau tidak normal bayi yang akan dilahirkan, nyeri yang akan dirasakan, dan sebagainya. ${ }^{3}$

Gangguan psikologis kecemasan selama kehamilan berhubungan dengan terjadinya indeks resistensi pada arteri uterin. Hal ini disebabkan oleh terjadinya peningkatan konsentrasi noradrenalin dalam plasma darah, sehingga aliran darah ke uterus terganggu. Uterus sangat sensitif terhadap noradrenalin dan dapat menimbulkan efek vasokontriksi. Mekanisme ini yang mengakibatkan terhambatnya proses partumbuhan dan perkembangan janin intra uterin karena kurangnya oksigen dan nutrisi sehingga terjadi kejadian berat badan lahir rendah (BBLR). Selain itu, kondisi stres dan cemas dapat merangsang peningkatan hormon kortikotropin yang diketahui berinteraksi dengan hormon oksitoksin dan progstaglandin. Hormon oksitoksin memediasi kontraksi uterus sehingga terjadi kelahiran sebelum waktunya. ${ }^{4}$

Klinik Sutra berlokasi di perbatasan Kecamatan Motoling dan Kecamatan Tompaso Baru. Jangkauan pelayanan meliputi, empat kecamatan yaitu Kecamatan Motoling, Tompaso Baru, Maesaan, dan Ranoyapo. Setiap bulan ibu yang bersalin di Klinik Sutra kurang lebih 20-25 ibu hamil dengan varian usia mulai dari 16-35 tahun.

Berdasarkan hasil survei awal didapatkan tiga orang ibu hamil primigravida yang hendak bersalin. Selain perasaan bahagia akan melihat anaknya, mereka juga mengalami cemas dikarenakan oleh berbagai faktor, di antaranya ialah ketakutan tidak dapat menjalani persalinan dengan alami atau normal, ragu-ragu dengan bidan yang akan menangani proses kelahiran, dan perasaan takut dengan kelahiran bayi apakah keadaan bayi normal. Tidak sedikit ibu yang mengkhawatirkan berat badan tidak akan kembali seperti sebe-lum hamil. Pada satu dari tiga ibu hamil didapatkan tingkat kecemasan berat disebabkan perasaan cemas yang berlebihan dan berkepanjangan sehingga aktivitasnya terganggu. Penelitian ini bertujuan untuk mengetahui gambaran tingkat kecemasan pada ibu hamil primigravida trimester III di Klinik
Bersalin Sutra Minahasa Selatan.

\section{METODE PENELITIAN}

Penelitian ini dilaksanakan di Klinik Bersalin Sutra Lindangan, Kecamatan Tompaso Baru, Kabupaten Minahasa Selatan pada Bulan September-November 2018. Metode penelitian yang digunakan dalam penelitian ini ialah deskriptif dengan desain potong lintang. Dilakukan wawancara dan pengisian kuesioner Hamilton Anxiety Rating Scale (HARS) untuk mengetahui derajat kecemasan. Populasi ialah seluruh ibu hamil yang berkunjung di Klinik Bersalin Sutra, dengan sampel penelitian berjumlah 32 orang.

\section{HASIL PENELITIAN}

Pada penelitian ini usia dikelompokan ke dalam kategori usia sesuai Depkes RI 2009. Kelompok usia 17-25 Tahun berjumlah 29 orang $(90,6 \%)$ dan kelompok usia 26-35 tahun berjumlah 3 orang $(9,4 \%)$. Responden ibu hamil dengan usia kehamilan terbanyak yaitu pada usia kehamilan 7 dan 9 bulan masing-masing berjumlah 11 orang $(34,4 \%)$ (Gambar 1).

\section{Usia Kehamilan}

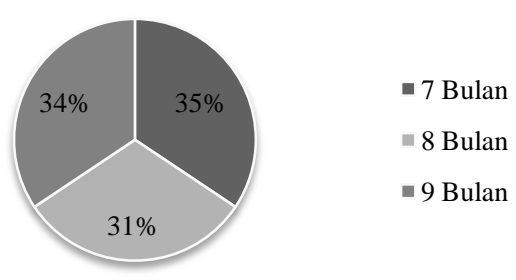

Gambar 1. Distribusi responden menurut usia kehamilan

Responden dengan status pernikahan telah menikah yang terbanyak dengan jumlah 29 orang $(90,6 \%)$ sedangkan yang tidak menikah berjumlah 3 orang $(9,4 \%)$. Responden yang bekerja sebagai ibu rumah tangga (ITR) berjumlah 30 orang $(93,8 \%)$ dan sisanya 2 orang $(6,3 \%)$ bekerja sebagai wiraswasta. Responden paling banyak berdiam di Kecamatan Tompaso Baru dengan jumlah 16 orang (50\%) (Gambar 2). Responden dengan pendidikan terakhir 
SMA yang terbanyak dengan jumlah 23 orang $(71 \%)$ sedangkan pendidikan terakhir SD hanya 1 orang (31\%) (Gambar 3).

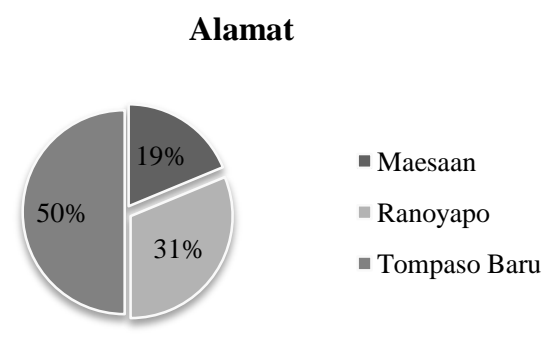

Gambar 2. Distribusi responden menurut kecamatan

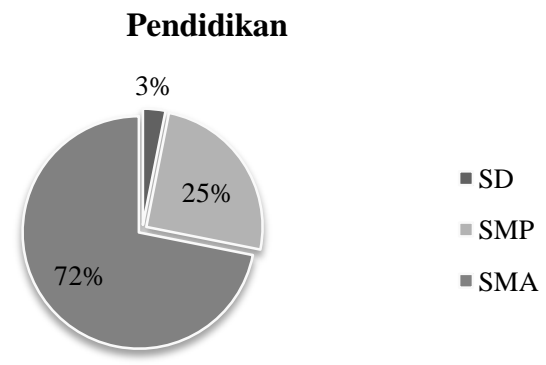

Gambar 3. Distribusi responden menurut pendidikan

Tingkat kecemasan pada ibu hamil diukur dengan kuesioner Hamilton Anxiety Rating Scale (HARS)

Tabel 1 memperlihatkan interpretasi dari skor yang didapat dari seluruh responden. Sebanyak 2 responden $(6,3 \%)$ tidak memiliki kecemasan, 6 responden $(18,8 \%)$ dengan kecemasan ringan, 14 responden $(43,8 \%)$ dengan kecemasan sedang, dan 10 responden $(31,3 \%)$ dengan kecemasan berat.
Tabel 1. Statistik interpretasi tingkat kecemasan

\begin{tabular}{ccc}
\hline $\begin{array}{c}\text { Tingkat } \\
\text { kecemasan }\end{array}$ & $\begin{array}{c}\text { Frekuensi } \\
(\mathbf{n})\end{array}$ & $\mathbf{( \% )}$ \\
\hline Tidak ada & 2 & 6,3 \\
kecemasan & & \\
Kecemasan ringan & 6 & 18,8 \\
Kecemasan & 14 & 43,8 \\
sedang & & \\
Kecemasan berat & 10 & 31,3 \\
Total & 32 & 100,0 \\
\hline
\end{tabular}

Tabel 2 memperlihatkan responden yang dominan mengalami kecemasan sedang pada usia 17-25 tahun sebanyak 12 orang $(37,5 \%)$ dan pada usia $26-35$ tahun sebanyak 2 orang $(6,3 \%)$.

Tabel 3 menunjukkan bahwa kecemasan yang paling sering ditemukan ialah kecemasan sedang sebesar $43,8 \%$ diikuti kecemasan berat sebesar 31,3\%.

Tabel 4 memperlihatkan responden yang sudah menikah dengan kecemasan berat sebanyak 10 orang $(31,3 \%)$ dan responden yang tidak menikah dengan kecemasan sedang sebanyak 3 orang $(9,4 \%)$.

Tabel 5 menunjukkan bahwa responden paling banyak mengalami kecemasan sedang yaitu 14 orang (43,8\%); seluruhnya berkerja sebagai IRT. Responden yang bekerja sebagai wiraswasta dengan kecemasan ringan sebanyak 1 orang $(3,1 \%)$ dan dengan kecemasan berat 1 orang $(3,1 \%)$.

Tabel 6 memperlihatkan bahwa responden yang mengalami kecemasan sedang terbanyak dengan pendidikan terakhir SMA yaitu sebanyak 10 orang $(31,3 \%)$; hanya 1 orang $(3,1 \%)$ mengalami kecemasan berat dengan pendidikan terakhir SD.

Tabel 1. Statistik interpretasi tingkat kecemasan

\begin{tabular}{ccc}
\hline $\begin{array}{c}\text { Tingkat } \\
\text { kecemasan }\end{array}$ & $\begin{array}{c}\text { Frekuensi } \\
(\mathbf{n})\end{array}$ & $\begin{array}{c}\text { Persentase } \\
(\mathbf{\%})\end{array}$ \\
\hline Tidak ada & 2 & 6,3 \\
kecemasan & & \\
Kecemasan ringan & 6 & 18,8 \\
Kecemasan & 14 & 43,8 \\
sedang & & \\
Kecemasan berat & 10 & 31,3 \\
Total & 32 & 100,0 \\
\hline
\end{tabular}


Tabel 2. Tabulasi silang usia dan tingkat kecemasan

\begin{tabular}{cclccccc}
\hline & & & Tidak ada & Ringan & Sedang & Berat & Total \\
\hline $\mathbf{U}$ & $17-25$ & Frekuensi (n) & 3 & 5 & 12 & 9 & 29 \\
$\mathbf{S}$ & tahun & Persentase & $9,4 \%$ & $15,6 \%$ & $37,5 \%$ & $28,1 \%$ & $90,6 \%$ \\
$\mathbf{I}$ & $26-35$ & Frekuensi (n) & 0 & 0 & 2 & 3 \\
$\mathbf{A}$ & tahun & Persentase & $0,0 \%$ & $0,0 \%$ & $6,3 \%$ & $3,1 \%$ & $40,6 \%$ \\
Total & & Frekuensi (n) & 3 & 5 & 14 & 10 & 32 \\
& & Persentase & $9,4 \%$ & $15,6 \%$ & $43,8 \%$ & $31,3 \%$ \\
\hline
\end{tabular}

Tabel 3. Tabulasi silang usia kehamilan dan tingkat kecemasan

\begin{tabular}{|c|c|c|c|c|c|c|c|}
\hline & & & Tidak ada & Ringan & Sedang & Berat & Total \\
\hline Usia & 7 bulan & Frekuensi (n) & 1 & 2 & 4 & 4 & 11 \\
\hline \multirow[t]{4}{*}{ kehamilan } & & Persentase & $3,1 \%$ & $6,3 \%$ & $12,5 \%$ & $12,5 \%$ & $34,4 \%$ \\
\hline & 8 bulan & Frekuensi (n) & 1 & 1 & 5 & 3 & 10 \\
\hline & 9 bulan & Frekuensi (n) & 0 & 3 & 5 & 3 & 11 \\
\hline & & Persentase & $0,0 \%$ & $9,4 \%$ & $15,6 \%$ & $9,4 \%$ & $34,4 \%$ \\
\hline \multicolumn{2}{|l|}{ Total } & Frekuensi (n) & 2 & 6 & 14 & 10 & 32 \\
\hline
\end{tabular}

Tabel 4. Tabulasi silang status pernikahan dan tingkat kecemasan

\begin{tabular}{|c|c|c|c|c|c|c|c|}
\hline & & & Tidak ada & Ringan & Sedang & Berat & Total \\
\hline \multirow{6}{*}{$\begin{array}{c}\text { Status } \\
\text { penikahan }\end{array}$} & Menikah & Frekuensi (n) & 2 & 6 & 11 & 10 & 29 \\
\hline & & Persentase & $6,3 \%$ & $18,8 \%$ & $34,4 \%$ & $31,3 \%$ & $90,6 \%$ \\
\hline & Tidak & Frekuensi (n) & 0 & 0 & 3 & 0 & 3 \\
\hline & \multirow{3}{*}{ Total } & Persentase & $0,0 \%$ & $0,0 \%$ & $9,4 \%$ & $0,0 \%$ & $9,4 \%$ \\
\hline & & Frekuensi (n) & 2 & 6 & 14 & 10 & 32 \\
\hline & & Persentase & $6,3 \%$ & $18,8 \%$ & $43,8 \%$ & $31,3 \%$ & $100,0 \%$ \\
\hline
\end{tabular}

Tabel 5. Tabulasi silang pekerjaan dan tingkat kecemasan

\begin{tabular}{|c|c|c|c|c|c|c|c|}
\hline & & & Tidak Ada & Ringan & Sedang & Berat & Total \\
\hline \multirow{5}{*}{$\begin{array}{l}\text { Pekerjaan } \\
\text { responden }\end{array}$} & IRT & Frekuensi (n) & 2 & 5 & 14 & 9 & 30 \\
\hline & & Persentase & $6,3 \%$ & $15,6 \%$ & $43,8 \%$ & $28,1 \%$ & $93,8 \%$ \\
\hline & Wiraswasta & Frekuensi (n) & 0 & 1 & 0 & 1 & 2 \\
\hline & & Frekuensi (n) & 2 & 6 & 14 & 10 & 32 \\
\hline & & Persentase & $6,3 \%$ & $18,8 \%$ & $43,8 \%$ & $31,3 \%$ & $100,0 \%$ \\
\hline
\end{tabular}

Tabel 6. Tabulasi silang pendidikan dan tingkat kecemasan

\begin{tabular}{|c|c|c|c|c|c|c|c|}
\hline & & & $\begin{array}{c}\text { Tidak ada } \\
\text { kecemasan }\end{array}$ & Ringan & Sedang & Berat & Total \\
\hline \multirow{6}{*}{$\begin{array}{c}\text { Pendidikan } \\
\text { terakhir }\end{array}$} & SD & Frekuensi (n) & 0 & 0 & 0 & 1 & 1 \\
\hline & & Persentase & $0,0 \%$ & $0,0 \%$ & $0,0 \%$ & $3,1 \%$ & $3,1 \%$ \\
\hline & SMP & Frekuensi (n) & 0 & 0 & 4 & 4 & 8 \\
\hline & & Persentase & $0,0 \%$ & $0,0 \%$ & $12,5 \%$ & $12,5 \%$ & $25,0 \%$ \\
\hline & SMA & Frekuensi (n) & 2 & 6 & 10 & 5 & 23 \\
\hline & & Persentase & $6,3 \%$ & $18,8 \%$ & $31,3 \%$ & $15,6 \%$ & $71,9 \%$ \\
\hline \multirow[t]{2}{*}{ Total } & & Frekuensi (n) & 2 & 6 & 14 & 10 & 0 \\
\hline & & Persentase & $6,3 \%$ & $18,8 \%$ & $43,8 \%$ & $31,3 \%$ & $0,0 \%$ \\
\hline
\end{tabular}

Tingkat kecemasan menurut faktor internal dan faktor eksternal penyebab kecemasan

Faktor-faktor penyebab timbulnya kecemasan pada ibu hamil dibagi menjadi faktor internal dan faktor eksternal. Faktor internal dibagi menjadi dua kategori, yaitu kepercayaan tentang persalinan dan perasaan menjelang persalinan. Faktor eksternal juga dibagi menjadi dua kategori, yaitu: informasi dari tenaga kesehatan dan dukungan suami. ${ }^{5}$ Data ini diambil dari hasil kuesioner melalui wawancara kepada responden.

Tabel 7 menampilkan kelompok responden yang mengatakan percaya akan cerita pengalaman orang lain atau mitos di daerahnya paling banyak mengalami kecemasan sedang yaitu sebanyak 13 orang $(52,0 \%)$ sedangkan kelompok responden yang mengatakan tidak percaya akan cerita pengalaman orang lain atau mitos di 
daerahnya yang mengalami tingkat kecemasan berat sebanyak 3 orang $(42,9 \%)$.

Tabel 8 memperlihatkan bahwa kelompok yang mengatakan takut menjelang persalinan paling banyak mengalami tingkat kecemasan sedang yaitu sebanyak 12 orang $(48,0 \%)$ sedangkan kelompok yang mengatakan tidak takut menjelang persalinan mengalami tingkat kecemasan ringan, sedang, dan berat masing-masing sebanyak 2 orang $(28,6 \%)$.

Tabel 9 menunjukkan bahwa responden yang mengatakan bahwa informasi dari tenaga kesehatan yang didapat baik paling banyak mengalami tingkat kecemasan sedang yaitu sebanyak 14 orang $(43,8 \%)$, kecemasan berat sebanyak 10 orang $(31,3 \%)$, dan kecemasan ringan sebanyak 6 orang $(18,8 \%)$, dan yang tidak mengalami kecemasan sebanyak 2 orang $(6,3 \%)$.

Tabel 10 memperlihatkan bahwa responden yang mengatakan suaminya mendukung kehamilannya terbanyak mengalami tingkat kecemasan sedang yaitu sebanyak 11 orang $(37,9 \%)$ sedangkan responden yang mengatakan bahwa suaminya tidak mendukung kehamilannya mengalami tingkat kecemasan sedang sebanyak 3 orang $(100 \%)$.

Tabel 7. Tingkat kecemasan responden menurut kepercayaan tentang persalinan

\begin{tabular}{|c|c|c|c|c|c|c|c|}
\hline & & & Tidak ada & Ringan & Sedang & Berat & Total \\
\hline \multirow{6}{*}{$\begin{array}{l}\text { Kepercayaan } \\
\text { tentang } \\
\text { persalinan }\end{array}$} & \multirow[t]{2}{*}{ Percaya } & Frekuensi (n) & 0 & 5 & 13 & 7 & 25 \\
\hline & & Persentase & $0,0 \%$ & $20,0 \%$ & $52,0 \%$ & $28,0 \%$ & $100,0 \%$ \\
\hline & \multirow{2}{*}{$\begin{array}{l}\text { Tidak } \\
\text { percaya }\end{array}$} & Frekuensi (n) & 2 & 1 & 1 & 3 & 7 \\
\hline & & Persentase & $28,6 \%$ & $14,3 \%$ & $14,3 \%$ & $42,9 \%$ & $100,0 \%$ \\
\hline & \multirow[t]{2}{*}{ Total } & Frekuensi (n) & 2 & 6 & 14 & 10 & 32 \\
\hline & & Persentase & $6,3 \%$ & $18,8 \%$ & $43,8 \%$ & $31,3 \%$ & $100,0 \%$ \\
\hline
\end{tabular}

Tabel 8. Tingkat kecemasan responden menurut perasaan menjelang persalinan

\begin{tabular}{cclccccc}
\hline & & Tidak ada & Ringan & Sedang & Berat & Total \\
\hline $\begin{array}{c}\text { Perasaan } \\
\text { menjelang } \\
\text { persalinan }\end{array}$ & Takut & Frekuensi (n) & 1 & 4 & 12 & 8 & 25 \\
& & Persentase & $4,0 \%$ & $16,0 \%$ & $48,0 \%$ & $32,0 \%$ & $100,0 \%$ \\
& Tidak & Frekuensi (n) & 1 & 2 & 2 & 2 & 7 \\
& Takut & Persentase & $14,3 \%$ & $28,6 \%$ & $28,6 \%$ & $28,6 \%$ & $100,0 \%$ \\
& & Frekuensi (n) & 2 & 6 & 14 & 10 & 32 \\
& & Persentase & $6,3 \%$ & $18,8 \%$ & $43,8 \%$ & $31,3 \%$ & $100,0 \%$ \\
\hline
\end{tabular}

Tabel 9. Tingkat kecemasan responden menurut informasi dari tenaga kesehatan

\begin{tabular}{lllcccc}
\hline & & Tidak ada & Ringan & Sedang & Berat & Total \\
\hline $\begin{array}{l}\text { Informasi } \\
\text { dari tenaga } \\
\text { kesehatan }\end{array}$ & Baik & Frekuensi (n) & 2 & 6 & 14 & 10 \\
& \multirow{2}{*}{ Total } & Persentase & $6,3 \%$ & $18,8 \%$ & $43,8 \%$ & $31,3 \%$ \\
& & Frekuensi (n) & 2 & 6 & 14 & $100,0 \%$ \\
& Persentase & $6,3 \%$ & $18,8 \%$ & $43,8 \%$ & 32 \\
\hline
\end{tabular}

Tabel 10. Tingkat kecemasan responden menurut dukungan suami

\begin{tabular}{|c|c|c|c|c|c|c|c|}
\hline & & & Tidak ada & Ringan & Sedang & Berat & Total \\
\hline \multirow{4}{*}{$\begin{array}{l}\text { Dukungan } \\
\text { suami }\end{array}$} & \multirow[t]{2}{*}{ Mendukung } & Frekuensi (n) & 2 & 6 & 11 & 10 & 29 \\
\hline & & Persentase & $6,9 \%$ & $20,7 \%$ & $37,9 \%$ & $34,5 \%$ & $100,0 \%$ \\
\hline & \multirow{2}{*}{$\begin{array}{c}\text { Tidak } \\
\text { Mendukung }\end{array}$} & Frekuensi (n) & 0 & 0 & 3 & 0 & 3 \\
\hline & & Persentase & $0,0 \%$ & $0,0 \%$ & $100,0 \%$ & $0,0 \%$ & $100,0 \%$ \\
\hline
\end{tabular}




\section{BAHASAN}

Penelitian ini dilaksanakan di Klinik Sutra Desa Lindangan, Kecamatan Tompaso Baru, Kabupaten Minahasa Selatan dari tanggal 20 September 2018 sampai 19 November 2018. Ibu hamil yang bersedia menjadi responden dan memenuhi kriteria inklusi berjumlah 32 orang. Pengisian kuesioner pada ibu hamil dilaksanakan ketika ibu hamil berkunjung memeriksakan kehamilan serta ibu hamil yang akan melahirkan.

Menurut Stuart dan Sundeen, ${ }^{6}$ terdapat empat tingkat kecemasan yaitu kecemasan ringan, kecemasan sedang, kecemasan berat, dan kecemasan sangat berat. Berdasarkan hasil penelitian ini didapatkan bahwa ibu hamil primigravida trimester III paling banyak mengalami kecemasan sedang.

Berdasarkan usia, didapatkan usia responden yang dominan ialah 18 tahun. Usia terbaik bagi perempuan untuk hamil dan melahirkan ialah 20-30 tahun. Pada usia ini keadaan kesehatan fisik dan mental perempuan dalam keadaan optimal. ${ }^{7} \mathrm{Hal}$ tersebut tidak selaras dengan hasil penelitian ini yang mendapatkan usia responden paling banyak pada usia terlalu muda (kurang dari 20 tahun). Menurut Depkes RI kategori usia remaja akhir ialah 17-25 Tahun dan dewasa awal ialah 26-35 tahun. Pada penelitian ini didapatkan ibu hamil yang dominan mengalami kecemasan sedang pada usia 17-25 tahun sebanyak 12 orang $(37,5 \%)$ sedangkan pada usia $26-35$ tahun terdapat 1 orang $(3,1 \%)$ dengan kecemasan berat dan 2 orang $(6,3 \%)$ dengan kecemasan sedang. Hal ini tidak sejalan dengan teori Potter dan Perry ${ }^{8}$ yang menyatakan bahwa individu dengan usia remaja rentan mengalami kecemasan dibandingkan individu dengan usia dewasa. Masa remaja merupakan masa transisi menuju usia dewasa dimana kondisi psikologis masih labil. Hasil penelitian ini mendapatkan responden usia dewasa awal dengan kecemasan berat. Hal ini mungkin disebabkan responden tersebut belum mampu menyesuaikan diri dengan peran baru menjadi seorang ibu.
Hasil penelitian mendapatkan 3 orang responden yang tidak menikah dan tidak mendapat dukungan dari suami; kesemuanya $(100 \%)$ mengalami kecemasan sedang. Kehamilan dengan pendampingan dan dukungan suami mempunyai efek yang lebih kecil terhadap terjadinya kecemasan dibandingkan persalinan yang tidak mendapat dukungan suami. ${ }^{9}$

Berdasarkan hasil penelitian ini, sebagian besar responden ibu hamil primigravida trimester ketiga ialah IRT yaitu sebanyak 30 orang $(93,8 \%)$ dan terdapat 14 orang $(43,8 \%)$ mengalami kecemasan sedang. Hal ini sejalan dengan penelitian Kusumawati et al. ${ }^{10}$ yang menyatakan bahwa ibu yang memiliki pekerjaan akan lebih sering bertemu dengan orang lain yang memungkinkannya mendapatkan informasi dan pengalaman tentang kehamilan dari orang lain. Selain itu, ibu yang memiliki pekerjaan dapat mengendalikan rasa cemas dengan lebih baik. Berbagai informasi serta pengalaman dari orang lain dapat mengubah cara pandang seseorang dalam menerima dan mengatasi kecemasan. $^{10}$

Hampir seluruh responden memiliki pendidikan terakhir SMA dengan jumlah 23 orang $(71 \%)$. Terdapat sebanyak 10 orang $(31,3 \%)$ dengan kecemasan sedang dan 5 orang $(15,6 \%)$ dengan kecemasan berat. Hal ini tidak sejalan dengan pernyataan Hawari ${ }^{11}$ yang mengemukakan bahwa status pendidikan yang kurang pada seseorang akan menyebabkan orang tersebut lebih mudah mengalami stres dibanding dengan mereka yang status pendidikan lebih tinggi atau baik. Hasil penelitian ini mendapatkan bahwa tingkat pendidikan seseorang kurang memengaruhi tingkat kecemasan.

Kepercayaan tentang persalinan berkaitan dengan rasa percaya responden dalam menanggapi cerita tentang persalinan dari orang lain atau mitos yang ada di daerahnya tersebut. Mitos yang dipercayai dapat menyebabkan kecemasan, seperti meminum air es dapat menggemukkan janin sehingga akan sulit dilahirkan; mandi pada malam hari akan membuat ketuban 
pecah dini; ibu hamil tidak boleh pergi menjenguk orang sakit atau melayat karena bayi akan sakit; rambut rontok menandakan tidak sehatnya bayi dalam kandungan; dan sebagainya. Pada penelitian ini didapatkan bahwa responden yang mengatakan percaya akan mitos paling banyak mengalami tingkat kecemasan sedang yaitu sebanyak 13 orang $(52,0 \%)$. Hal ini sesuai dengan penelitian Roisa yang mendapatkan bahwa 32 responden yang mengatakan percaya dengan cerita pengalaman orang lain/mitos di daerahnya mengalami tingkat kecemasan berat, sedang, dan ringan. ${ }^{5}$ Hal ini menunjukkan adanya hubungan tingkat kecemasan dengan pikiran ibu hamil dengan kepercayaan yang tidak benar.

Berdasarkan hasil penelitian ini dapat diketahui bahwa pada kelompok yang menyatakan takut menjelang persalinan mengalami tingkat kecemasan berat sebanyak 8 orang $(32,0 \%)$. Pada kelompok yang menyatakan tidak takut menjelang persalinan mengalami tingkat kecemasan ringan, sedang, dan berat masing-masing sebanyak 2 orang $(28,6 \%)$, sedangkan responden yang tidak mengalami kecemasan sebanyak 1 orang (14,3\%). Hal ini sejalan dengan pernyataan Rahmaiah ${ }^{12}$ bahwa kecemasan dan ketakutan paling sering terjadi pada usia kehamilan menjelang persalinan disebabkan oleh berbagai pemikiran ibu hamil, antara lain ketakutan akan bayi apakah lahir normal atau tidak, nyeri yang akan dirasakan, dan sebagainya.

Informasi dari tenaga kesehatan merupakan faktor eksternal yang sangat penting bagi ibu hamil. Berdasarkan hasil penelitian ditemukan sebanyak 32 responden (100\%) mendapat informasi dengan baik. Peran petugas kesehatan sangat dibutuhkan untuk mengurangi risiko buruk pada kehamilan. Petugas kesehatan sebagai edukator berperan dalam melaksanakan bimbingan atau penyuluhan khususnya yang berhubungan dengan kesehatan reproduksi termasuk dengan mengatasi kecemasan pada kehamilan. ${ }^{13}$ Berbeda dengan hasil penelitian yang didapatkan yaitu meskipun informasi dari tenaga kesehatan didapatkan dengan baik, namun kurang berperan terhadap tingkat kecemasan ibu hamil. Hal ini mungkin disebabkan karena pendampingan yang kurang serta keraguan responden terhadap tenaga kesehatan.

Dukungan suami merupakan faktor eksternal yang memengaruhi tingkat kecemasan responden dalam menghadapi persalinan. Hasil penelitian ini tidak selaras dengan penelitian oleh Mu'minah ${ }^{14}$ yang mendapatkan adanya hubungan antara dukungan sosial suami dengan tingkat kecemasan ibu bersalin. Pada penelitian ini didapatkan bahwa dukungan dari suami kurang memengaruhi tingkat kecemasan ibu hamil. Hal ini mungkin disebabkan oleh faktor pekerjaan suami yang tidak bisa menemani saat menjelang persalinan.

\section{SIMPULAN}

Berdasarkan hasil penelitian ini dapat disimpulkan bahwa tingkat kecemasan pada ibu hamil primigravida trimester III di Klinik Sutra Minahasa Selatan yang terbanyak ialah kecemasan sedang, diikuti kecemasan berat dan kecemasan ringan. Sebagian kecil ibu hamil tidak mengalami kecemasan.

Terjadinya kecemasan dapat disebabkan oleh usia, tingkat pendidikan, pekerjaan, kepercayaan tentang persalinan, perasaan menjelang persalinan, informasi dari tenaga kesehatan, dan dukungan suami.

\section{SARAN}

Diharapkan tenaga kesehatan di klinik, baik bidan dan pegawai lebih meningkatkan pemberian penyuluhan, khususnya kepada ibu hamil yang masih percaya akan mitos kehamilan. Diharapkan ibu hamil melakukan pemeriksaan secara rutin selama kehamilan agar dapat menambah informasi selama kehamilan yang meliputi tanda-tanda kehamilan dan perubahan fisiologik agar dapat mengurangi terjadinya kecemasan.

Disarankan untuk melakukan penelitian lanjut terhadap faktor-faktor yang lebih dominan dalam memengaruhi kecemasan ibu hamil primigravida trimester III. 


\section{DAFTAR PUSTAKA}

1. Maramis WF. Catatan Ilmu Kedokteran Jiwa (2nd ed). Surabaya: Airlangga University Press, 2009.

2. Husna D. Perbedaan tingkat kecemasan dalam menghadapi persalinan pada ibu hamil nullipara dan multipara trimester III. Universitas Airlangga Surabaya; 2013. [Cited 2018 Aug 12] Available from: http://Journal.Unair.Ac.Id/DownloadFullpapers-Msj6d80497333full.Pdf

3. Usman FR, Kundre RM, Onibala F Perbedaan tingkat kecemasan ibu hamil menghadapi persalinan dengan kepatuhan antenatal care (ANC) di Puskesmas Bahu Kota Manado. Universitas Sam Ratulang; 2016. [cited 2018 Aug 12] Available from: https://ejournal.unsrat.ac.id/index.php/jkp /article/view/10794/10383

4. Qureshi F, Alam J, Masood AK \& Sheraz. Effect of examination stres on blood cell parameters of students in a Pakistani Medical College. Department of Physiology. Women Medical College. Abbottabad, 2002. [cited 2018 Aug 18] Available from: http://repository.usu. ac.id/bitstream/handle/123456789/21565 /ChapterII.pdf;jsessionid=43E25F20A64 A4E92043EC8CEB5FDBBDB?sequenc $\mathrm{e}=4$

5. Shodiqoh ER, Fahriani S. Perbedaan tingkat kecemasan dalam menghadapi persalinan antara primigravida dan multigravida. Fakultas Kesehatan Universitas Airlangga. Surabaya; 2014. [cited 2018 Aug 20]. Available from: http: //download. portalgaruda.org/article.php? article $=306829 \&$ val $=1122 \&$ title $=$ Anxiet y\%20Level\%20Differences\%20Between $\% 20$ The $\% 20$ Face $\% 20$ Of\% 20Labour\%2 0And\%20Multigravida\%20Primigravida
6. Stuart GW. Buku Saku Keperawatan Jiwa (5th ed). Ramona P. Kapoh, Egi Komara Yudha, alih bahasa. Jakarta: EGC, 2013.

7. Sofian A, Rustam M. Sinopsis Obstetri: Obstetri Fisiologi, Obstetri Patologi Jilid 1 (3rd ed). Jakarta: EGC, 2013.

8. Potter A, Perry G. Buku Ajar Fundamental Keperawatan: Konsep, Proses dan Praktik Vol. 1 (4th ed). Jakarta: EGC, 2005.

9. Kusumawati F, Hartono Y. Buku Ajar Keperawatan Jiwa. Jakarta: Salemba Medika, 2010.

10. Kusumawati E. Hubungan Pengetahuan primigravida tentang kehamilan dengan kecemasan menghadapi kehamilan trimester I di BPS Fathonah WN. Jurnal Kesmadaska. 2011;2(2). ISSN: 20875002. [cited 2018 Nov 20]. Available from: http://download.portalgaruda.org/ article.php?article $=119628 \& \mathrm{val}=5479$

11. Hawari D. Manajemen Stres Cemas dan Depresi. Jakarta: Balai Penerbit FKUI, 2008; p.3-78.

12. Rahmamiah S. Kecemasan bagaimana mengatasi penyebabnya. Jakarta: Pustaka Obor, 2003

13. Lesesne CA, Lewis KM, White CP, Green DC, Duffy JL, Wandersman A. Promoting science-based approaches to teen pregnancy prevention: proactively engaging the three systems of the interactive systems frame-work. Am J Community Psychol. 2008;41(3-4): 379-92.

14. Mu'minah I. Hubungan dukungan sosial dengan tingkat kecemasan ibu bersalin kala I di puskesmas Mergangsan Kota Yogyakarta. Yogyakarta; 2013 [cited 2018 Nov 22]. Available from: http://opac.unisayogya.ac.id/1418/1/NAS KAH\%20PUBLIKASI_Ikhwah\%20Mu $\%$ E2\%80\%99minah.pdf. 